\title{
Perbankan Syariah dan Pertumbuhan Ekonomi Indonesia: Bagaimana Kontribusinya?
}

\section{Islamic Banking and Indonesia's Economic Growth: How it Contributes?}

\author{
Emy Widyastuti ${ }^{1}$, Yusvita Nena Arinta ${ }^{2}$ \\ ${ }^{1}$ Institut Agama Islam Negeri Salatiga, Salatiga 57021, emywidyastuti@iainsalatiga.ac.id \\ ${ }^{2}$ Institut Agama Islam Negeri Salatiga, Salatiga 57021, nena@iainsalatiga.ac.id
}

\begin{abstract}
Islamic banking takes part in the Indonesian economic and financial system which contributes to the dynamics of eeconomic growth. The number of Islamic banks in Indonesia, through its market share, is still quite small, namely 5.95\% in 2019 of the total national banking market share. One of the main activities of Islamic banking is channeling financing through financing based on the type of use and business category. This study aims to determine the short-term and long-term contribution of Islamic banking to Indonesia's economic growth using the Vector Error Correction Model (VECM) method. The data used in this study are quarterly secondary data of real Gross Domestic Product (GDP) and financing based on the use and category of Indonesian Islamic banking business types, which consist of working capital financing, investment financing and consumption financing. The results showed that in the short and long term, the variable consumption financing had a significant negative effect on Indonesia's economic growth.
\end{abstract}

Keywords: Consumption financing, investment financing, working capital financing

\begin{abstract}
Abstrak. Perbankan syariah mengambil menjadi bagian dalam sistem perekonomian dan keuangan Indonesia yang ikut memberikan dinamika pertumbuhan ekonomi. Jumlah perbankan syariah di Indonesia melalui pangsa pasarnya masih terbilang cukup kecil yaitu sebesar $5.95 \%$ pada tahun 2019 dari keseluruhan pangsa pasar perbankan nasional. Salah satu kegiatan utama perbankan syariah adalah menyalurkan pembiayaan melalui pembiayaan berdasarkan jenis penggunaan dan kategori usaha. Penelitian ini bertujuan untuk mengetahui kontribusi jangka pendek dan jangka panjang perbankan syariah terhadap pertumbuhan ekonomi Indonesia dengan menggunakan metode Vector Error Correction Model (VECM). Data yang digunakan dalam penelitian ini adalah data sekunder triwulanan Gross Domestic Product (GDP) riil dan pembiayaan berdasarkan penggunaan dan kategori jenis usaha perbankan syariah Indonesia yang terdiri dari pembiayaan modal kerja, pembiayaan investasi, dan pembiayaan konsumsi. Hasil penelitian menunjukkan bahwa dalam jangka pendek dan jangka panjang, variabel pembiayaan konsumsi berpengaruh negatif signifikan terhadap pertumbuhan ekonomi Indonesia.
\end{abstract}

Kata kunci: Pembiayaan investasi, pembiayaan konsumsi, pembiayaan modal kerja

\section{PENDAHULUAN}

Perkembangan ekonomi dalam suatu negara dapat diukur dengan pertumbuhan ekonomi, sehingga pertumbuhan ekonomi menjadi tujuan utama perekonomian sebuah negara (BPS, 2019). Pemerintah berupaya meningkatkan pertumbuhan ekonomi melalui serangkaian kebijakan moneter dan nonmoneter. Gross Domestic Bruto (GDP) atau Produk Domestik Bruto (PDB) riil merupakan ukuran yang digunakan untuk mengukur pertumbuhan ekonomi. Laju pertumbuhan ekonomi di Indonesia telah menjadi fenomena menarik dalam kurun waktu yang cukup lama, apalagi dengan dual banking system yang dianut oleh Indonesia. Perbankan syariah yang merupakan manivestasi dari ekonomi syariah merupakan solusi untuk mengatasi krisis ekonomi baik jangka pendek maupun dalam jangka panjang. Pertumbuhan ekonomi yang baik akan menjaga kestabilan ekonomi dalam sebuah negara (Rusliani, 2018).

Berlakunya Undang-Undang No. 21 Tahun 2008 tentang Perbankan Syariah, diharapkan mampu mendorong pertumbuhan ekonomi yang lebih cepat karena sudah memiliki landasan hukum yang memadai (OJK, 2019). Saat ini kontribusi sektor keuangan terhadap sektor ekonomi riil telah menjadi kajian, sehingga banyak penelitian yang membahas tentang pentingnya pembangunan sektor 
keuangan untuk pertumbuhan ekonomi. Keberadaan bank syariah mungkin saja tidak berdampak terhadap profitabilitas, tetapi ternyata telah membuat industri perbankan menjadi lebih stabil (Rizvi et al., 2019). Awal kehadiran perbankan syariah ditandai dengan lahirnya Bank Muamalat Indonesia (BMI) pada tahun 1991. Sampai saat ini, jumlah perbankan syariah Indonesia adalah sebanyak 198 bank yang terdiri dari 14 Bank Umum Syariah (BUS), 20 Unit Usaha Syariah (UUS) dan 164 Bank Pembiayaan Rakyat Syariah (BPRS).

Secara umum industri perbankan syariah di Indonesia telah menunjukkan perkembangan yang cukup baik, yang ditandai dengan adanya peningkatan layanan di hampir seluruh wilayah Indonesia (Afandi \& Amin, 2019). Pada akhir tahun 2019, market share perbankan syariah Indonesia sebesar $5.95 \%$ dari keseluruhan market share perbankan nasional Indonesia. Market share tersebut terdiri dari total aset, pembiayaan yang disalurkan (PYD) dan Dana Pihak Ketiga (DPK). Pembiayaan yang disalurkan oleh perbankan syariah mengalami pertumbuhan setiap tahunnya. Pada akhir tahun 2019, jumlah PYD sebesar 353.9 miliar rupiah meningkat dari tahun 2018 yaitu sebesar 316 miliar rupiah (OJK, 2019). Pembiayaan yang disalurkan oleh perbankan syariah di antaranya pembiayaan modal kerja, pembiayaan investasi dan pembiayaan konsumsi dengan jumlah yang meningkat setiap tahunnya.

Tabel 1 Jumlah pembiayaan berdasarkan jenis penggunaan dan kategori usaha perbankan syariah tahun 2010-2019 (miliar rupiah)

\begin{tabular}{cccccc}
\hline Tahun & $\begin{array}{c}\text { Pembiayaan } \\
\text { Modal Kerja }\end{array}$ & $\begin{array}{c}\text { Pembiayaan } \\
\text { Investasi }\end{array}$ & $\begin{array}{c}\text { Pembiayaan } \\
\text { Konsumsi }\end{array}$ & $\begin{array}{c}\text { Total } \\
\text { Pembiayaan }\end{array}$ & $\begin{array}{c}\text { Pertumbuhan } \\
\text { Pembiayaan } \\
\text { Per Tahun (\%) }\end{array}$ \\
\hline 2010 & 31,855 & 13,416 & 22,910 & 68,181 & - \\
2011 & 41,698 & 17,903 & 43,053 & 102,655 & 33.58 \\
2012 & 56,097 & 26,585 & 64,823 & 147,505 & 30.40 \\
2013 & 71,566 & 33,839 & 78,715 & 184,120 & 19.88 \\
2014 & 77,935 & 41,718 & 79,677 & 199,330 & 7.63 \\
2015 & 79,949 & 51,690 & 81,357 & 212,996 & 6.41 \\
2016 & 87,363 & 60,042 & 100,602 & 248,007 & 14.11 \\
2017 & 99,825 & 66,848 & 119,021 & 285,695 & 13.19 \\
2018 & 105,055 & 75,730 & 139,408 & 320,193 & 10.77 \\
2019 & 110,586 & 86,972 & 157,624 & 355,182 & 9.85 \\
\hline
\end{tabular}

Sumber: OJK, 2019

Pembiayaan yang disalurkan oleh perbankan syariah kepada masyarakat untuk setiap kategori tersebut diharapkan dapat memberikan profitabilitas untuk perbankan syariah dan dapat memberikan kontribusi terhadap pertumbuhan ekonomi nasional. Sistem ekonomi dan perbankan telah mengambil peran dalam memengaruhi pertumbuhan ekonomi suatu negara. Beberapa penelitian tentang pertumbuhan ekonomi membahas dan berfokus pada pengaruh aset, pembiayaan yang disalurkan dan dana pihak ketiga terhadap pertumbuhan ekonomi.

Pembiayaan yang diberikan oleh perbankan syariah memengaruhi pertumbuhan ekonomi karena akan meningkatkan sumber modal dan aktivitas ekonomi dalam jangka panjang (El Ayyubi et al., 2018). Pembiayaan tersebut mencakup seluruh pembiayaan yang disalurkan (PYD) oleh perbankan syariah, namun belum diketahui pembiayaan mana yang memberikan kontribusi untuk pertumbuhan ekonomi baik jangka pendek maupun jangka panjang. Penelitian yang dilakukan oleh Afandi \& Amin (2019) terkait pengaruh pembiayaan modal kerja, pembiayaan investasi dan pembiayaan konsumtif di 33 provinsi di Indonesia terhadap pertumbuhan ekonomi menunjukkan bahwa ketiga pembiayaan tersebut tidak berpengaruh terhadap pertumbuhan ekonomi Indonesia, sehingga keberadaan perbankan syariah di Indonesia belum memberikan dampak yang signifikan terhadap kesejahteraan masyarakat Indonesia. 
Pembiayaan modal kerja, pembiayaan investasi maupun pembiayaan konsumsi merupakan pembiayaan yang secara langsung berhubungan dengan aktivitas masyarakat. Penelitian ini bertujuan untuk mengetahui kontribusi jangka pendek dan jangka panjang pembiayaan yang disalurkan perbankan syariah melalui pembiayaan modal kerja, pembiayaan investasi dan pembiayaan konsumsi terhadap pertumbuhan ekonomi di Indonesia. Kebaruan dari penelitian ini terletak pada variabel yang digunakan untuk mengetahui kontribusi jangka pendek dan jangka panjang perbankan syariah terhadap pertumbuhan ekonomi dengan menggunakan metode Vector Error Correction Model (VECM).

\section{TINJAUAN PUSTAKA}

Pertumbuhan ekonomi adalah sebuah proses dalam perekonomian yang menyebabkan bertambahnya barang dan jasa melalui peningkatan kapasitas produktif dalam perekonomian secara terus menerus serta meningkatnya kemakmuran dalam suatu negara (Mahzalena \& Juliansyah, 2019). Pertumbuhan ekonomi dalam suatu negara dipengaruhi oleh banyak faktor. Faktor-faktor yang memengaruhi pertumbuhan ekonomi adalah variabel pertumbuhan (modal manusia, pendapatan awal, investasi, inovasi, serta pertumbuhan populasi), demografi (angka harapan hidup), kebijakan makro ekonomi, dan institusi (He \& Xu, 2019). Faktor investasi, demografi, pendidikan, perdagangan, dan agama berpengaruh pada pertumbuhan ekonomi (Sarwer et al., 2013).

Peran variabel investasi, sumber daya manusia, kesuburan, dan kelembagaan serta kebijakan merupakan faktor penentu pertumbuhan ekonomi. Pengaruh sektor jasa keuangan dan asuransi memberikan kontribusi terhadap pertumbuhan ekonomi Indonesia (GDP) sebesar 443,041.6 miliar rupiah pada tahun 2019 dari total GDP Indonesia pada tahun yang sama sebesar 10,949,243.70 miliar rupiah, sedangkan kontribusi perbankan syariah dalam menyumbang GDP Indonesia pada tahun 2019 adalah sebesar 267,387 miliar rupiah (BPS, 2019).

Pertumbuhan ekonomi di kawasan Asia disebabkan karena adanya pertumbuhan yang kuat dalam akumulasi modal (Lee \& Hong, 2012). Sektor keuangan terbukti memiliki pengaruh positif yang signifikan terhadap pertumbuhan produktivitas faktor total, yang selanjutnya berdampak positif terhadap pertumbuhan GDP secara keseluruhan. Pertumbuhan ekonomi yang didefinisikan sebagai peningkatan Produk Nasional Bruto (PNB) atau kenaikan Gross Domestic Bruto (GDP) atau Produk Domestik Bruto (PDB) telah menjadi tujuan utama sebagian besar studi ekonomi hingga saat ini. Bahkan saat ini pertumbuhan ekonomi masih menjadi topik serius yang penting didiskusikan di antara para ekonom.

Intermediasi keuangan memainkan peran penting dalam memobilisasi tabungan, yang akan meningkatkan kumpulan modal sehingga dapat diinvestasikan dalam kegiatan produksi. Sehubungan dengan hal tersebut, upaya pengembangan sektor keuangan dipandang sebagai salah satu cara yang dapat digunakan dalam upaya peningkatan kapasitas produktif perekonomian. Penghimpunan dana termasuk sebagai langkah liberalisasi keuangan yang akan berpengaruh pada jumlah pembiayaan yang disalurkan yang pada akhirnya akan diinvestasikan melalui modal kerja dan oleh karena itu akan meningkatkan pertumbuhan (Majid \& Kassim, 2015).

Pembiayaan bank syariah telah memberikan kontribusi terhadap peningkatan investasi jangka panjang dan positif (Tabash \& Dhankar, 2014). Meskipun saat ini ukurannya relatif kecil jika dibandingkan dengan perekonomian dan ukuran keuangan secara keseluruhan dalam sistem, perbankan Islam dikaitkan secara positif dengan pertumbuhan ekonomi, bahkan setelah berhasil mengendalikan berbagai faktor penentu pertumbuhan negara non-Islam yang mengadopsi beberapa amalan dari perbankan Islam sesuai peraturan perbankan sehingga dapat membantu memacu pertumbuhan (Imam \& Kpodar, 2016).

Keuangan Islam telah memberikan kontribusi terhadap pertumbuhan keuangan di Malaysia. Perbankan syariah layak, dapat diterima dan sangat efektif dalam mengembangkan ekonomi karena 
sistem ekonomi mempunyai hubungan secara langsung dengan pertumbuhan dan pengembangan. Tingkat pertumbuhan pendapatan nasional dapat mendorong perekonomian melalui pembiayaan investasi yang produktif dan perbankan syariah berupaya untuk mengatasi permasalahan perekonomian melalui pemerataan pendapatan (Sarwer et al., 2013). Awal dari tujuan dan tugas sistem perbankan syariah adalah kesejahteraan ekonomi dengan lapangan kerja penuh, tingkat pertumbuhan ekonomi yang optimal, serta distribusi pendapatan dan kekayaan yang merata.

Dalam studi peneliti lain, dalam jangka panjang, pembiayaan bank syariah berpengaruh positif dan signifikan berkorelasi dengan pertumbuhan ekonomi dan akumulasi modal di negara-negara Malaysia, Indonesia, Bahrain, UEA, Arab Saudi, Mesir, Kuwait, Qatar, dan Yaman. Hasil tersebut diperoleh dari uji kausalitas Granger yang mengungkapkan hasil positif dan signifikan secara statistik hubungan antara pertumbuhan ekonomi dan pembiayaan bank syariah dalam jangka pendek dan panjang, bahkan hubungan jangka panjang lebih kuat daripada jangka pendek (Farahani \& Dastan, 2013). Terdapat hubungan jangka panjang antara perbankan syariah dengan pertumbuhan ekonomi di kawasan Asia Tenggara. Lembaga keuangan dapat digunakan untuk mendongkrak dan berkontribusi terhadap pertumbuhan ekonomi serta mempunyai hubungan yang positif antara perbankan syariah dan pertumbuhan ekonomi karena stabilitas, efisiensi dan profitabilitas pembiayaan dijamin dengan adanya skema PLS (Profit and Loss Sharing) yang ada dalam perbankan syariah (Lebdaoui \& Wild, 2016).

Keberadaan perbankan syariah mempunyai potensi mengangkat kelompok rentan (petani dan Usaha Kecil dan Menengah) serta mendorong pertumbuhan ekonomi yang inklusif (Fasih, 2012). Studi yang dilakukan di Malaysia dan Indonesia terhadap perbankan syariah menunjukkan bahwa di dua negara tersebut perbankan syariah berkontribusi terhadap pertumbuhan ekonomi baik dalam jangka pendek maupun jangka panjang. Bahkan di kedua negara tersebut kontribusi jangka pendek lebih besar jika dibandingkan dengan negara-negara Asia Timur serta negara-negara teluk lainnya (Yusof \& Bahlous, 2013). Terdapat hubungan dua arah yang signifikan jangka pendek dan jangka panjang antara deposito perbankan syariah dan kantor terhadap pertumbuhan ekonomi (Anwar et al., 2020). Selain itu, pangsa pasar bank syariah memiliki hubungan positif terhadap pengembangan intermediasi keuangan, pendalaman keuangan serta kesejahteraan ekonomi khususnya di negara-negara berpenghasilan rendah atau mayoritas Muslim (Abedifar et al., 2016).

Pembiayaan bank syariah dan kontribusinya terhadap pertumbuhan ekonomi di Malaysia menunjukkan bahwa dalam jangka panjang, PDB Malaysia tidak sensitif terhadap pembiayaan bank syariah. Hasil ini dapat dijelaskan oleh struktur pembiayaan bank syariah yang memarjinalkan instrumen berbasis profit and loss sharing (PLS) yang sejalan dengan kenyataan ekonomi di Malaysia, di mana bank syariah lebih banyak terlibat kegiatan nonpartisipatif yang secara umum berdampak jangka pendek (Hachicha \& Amar, 2015).

Hasil penelitian yang dilakukan Afandi \& Amin (2019) menunjukkan hasil berbeda. Penelitian tersebut menunjukkan bahwa keberadaan pembiayaan bank syariah saat ini tidak berdampak dan belum memberikan pengaruh yang signifikan terhadap pertumbuhan ekonomi dan kesejahteraan masyarakat Indonesia. Penelitian yang dilakukan terhadap pembiayaan modal kerja, pembiayaan investasi dan pembiayaan konsumtif di 33 provinsi di Indonesia terhadap pertumbuhan ekonomi menunjukkan bahwa ketiga pembiayaan tersebut tidak berpengaruh terhadap pertumbuhan ekonomi Indonesia. Hal ini menyimpulkan bahwa keberadaan perbankan syariah di Indonesia belum memberikan dampak yang signifikan terhadap kesejahteraan masyarakat Indonesia.

\section{METODE}

Data yang digunakan dalam penelitian ini adalah data sekunder berupa data triwulanan dari triwulan 1 tahun 2010 sampai dengan triwulan IV tahun 2019 yang bersumber dari Statistik Perbankan Syariah (SPS) yang dipublikasikan oleh Otoritas Jasa Keuangan (OJK) untuk data pembiayaan modal kerja, pembiayaan investasi dan pembiayaan konsumsi. Sedangkan data GDP berasal dari Badan Pusat 
Statistik (BPS) Indonesia. Data diolah menggunakan Eviews 8 dengan metode analisis deskriptif kuantitatif dan menggunakan alat analisis Vector Autoregression (VAR) dengan ketentuan jika data yang digunakan stasioner pada level, namun jika data yang digunakan stasioner pada first difference maka menggunakan metode Vector Error Correction Model (VECM). VECM menawarkan suatu prosedur kerja yang mudah untuk dapat memisahkan komponen jangka panjang (long-run) dan komponen jangka pendek (short-run) dari proses pembentukan data. Dengan demikian VECM berbeda dengan VAR dimana pada VECM dapat digunakan untuk memodelkan data time series yang terkointegrasi dan tidak stasioner, sehingga VECM sering disebut dengan bentuk VAR yang terestriksi (Sulistiana, 2017).

Metode VAR pertama kali ditemukan oleh Sims pada tahun 1980 dan merupakan salah satu analisis multivariate yang menyediakan cara sistematis dalam menangkap perubahan yang dinamis dalam multiple time series, serta memiliki pendekatan yang kredibel dan lebih mudah dipahami untuk pendeskripsian data dan peramalan, inferensi struktural, serta analisis kebijakan. Hasil estimasi model VAR dapat dilihat melalui Impulse Response Function (IRF) dan Variance Decomposition (VDC) suatu variabel terhadap variabel lainnya atau terhadap dirinya sendiri baik IRF maupun VDC.

VECM yang dikembangkan oleh Johansen dan Juselius pada tahun 1990 sebagai konsep bentuk VAR yang teretriksi menawarkan prosedur kerja yang mudah untuk memisahkan komponen jangka panjang dan jangka pendek. Retriksi tambahan ini diberikan karena keberadaan bentuk data yang tidak stasioner pada tingkat level, sehingga model VECM dapat digunakan untuk memodelkan data tersebut (Sulistiana, 2017). Hal ini sesuai dengan tujuan penelitian yaitu untuk mengetahui kontribusi jangka panjang dan jangka pendek perbankan syariah terhadap pertumbuhan ekonomi Indonesia.

$$
\begin{aligned}
& \Delta \Upsilon_{t}=\mu_{0 x}+\mu_{1 x^{t}}+\pi_{x} \Upsilon_{t-1}+\sum_{i=1}^{k-1} \text { rix. } \Delta \Upsilon_{t-1}+\sum_{t} \\
& \text { Keterangan: } \\
& \text { yt : Vektor yang berisi variabel yang dianalisis dalam penelitian } \\
& \mu 0 \mathrm{x} \quad \text { : Vektor intersep } \\
& \mu 1 \mathrm{x} \quad \text { : Vektor koefisien } \\
& \mathrm{t} \quad \text { : Time trend } \\
& \pi \mathrm{x} \quad: \alpha \mathrm{x}, \beta^{\mathrm{y}} \text { di mana } \mathrm{b} \text { mengandung persamaan kointegrasi jangka panjang } \\
& y \mathrm{t}-1 \quad \text { : Variabel in-level } \\
& \text { rix : Matriks koefisien regresi } \\
& k-1 \text { : Ordo VECM dari VAR } \\
& \text { et : Error term }
\end{aligned}
$$

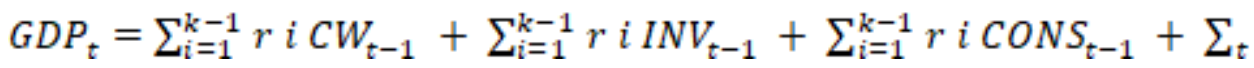

Keterangan:

GDP : Gross Domestic Product (Pertumbuhan ekonomi)

CW : Pembiayaan modal kerja

INV : Pembiayaan investasi

CONS : Pembiayaan konsumsi

\section{Uji Stasioneritas Data}

Stasioneritas data diamati dengan menggunakan metode Augmented Dickey-Fuller (ADF) dengan kriteria keputusan pada tingkat signifikansi $(1-\alpha) 100 \%$, apabila probabilitasnya kurang dari taraf nyata $1 \%$ atau $5 \%$, maka data tersebut stasioner pada taraf tersebut. Data yang stasioner akan diestimasi dengan menggunakan VAR dengan metode standar. Sedangkan data yang tidak stasioner akan memiliki kemungkinan memiliki dua pilihan VAR, yaitu VAR dalam bentuk first difference atau VECM. Dengan adanya variabel yang tidak stasioner akan memunculkan kemungkinan adanya hubungan kointegrasi antar variabel. Pengujian stasioner ini dilakukan dengan uji akar unit. Uji akar unit dilakukan untuk menghindari terjadinya regresi lancung (spurious regression), yaitu sebuah regresi yang menggambarkan hubungan antara dua variabel signifikan secara statistik padahal 
kenyataannya tidak. Data dinyatakan stasioner jika nilai rata-rata dalam varian tidak mengalami perubahan secara sistematik sepanjang waktu. Pada data time series, data memiliki nilai rata-rata yang beragam sehingga menyebabkan data menjadi tidak stasioner (Nursyah, 2013).

\section{Uji Lag Optimum}

Dalam VAR, lag berguna untuk menunjukkan seberapa lamakah reaksi suatu variabel terhadap variabel lainnya dan untuk menghilangkan autokorelasi dalam VAR. Pengujian ini memanfaatkan beberapa kriteria yaitu dengan Schwarz Criterion (SC), Akaike Information Criterion (AIC), HananQuinn (SQ) dan Likelihood Ratio (LR). Uji lag digunakan untuk menentukan panjang lag optimum yang akan digunakan untuk analisis selanjutnya. Uji lag optimum merupakan langkah penting yang harus dilakukan dalam menggunakan model VECM. Untuk langkah awal akan dilihat panjang selang maksimum sistem VAR yang stabil. Suatu sistem VAR dikatakan stabil atau stasioner jika seluruh akar unitnya memiliki modulus lebih kecil dari satu dan semuanya terletak di dalam unit circle.

\section{Uji Stabilitas VAR}

Uji stabilitas VAR dilakukan untuk menghitung akar-akar dari fungsi polinomial atau dikenal dengan roots of characteristic polynomial dengan menghitung akar-akar dari fungsi polinomial. Model VAR tersebut dikatakan stabil, apabila semua akar dari fungsi polinomial tersebut berada di dalam unit circle atau jika nilai absolutnya lebih kecil dari satu sehingga IRF dan FEVD yang dilakukan dianggap valid.

\section{Uji Kointegrasi}

Metode uji Engle-Granger dua langkah dan uji Johansen digunakan untuk menguji adanya kointegrasi dengan tujuan untuk menentukan ada atau tidaknya variabel-variabel yang tidak stasioner terkointegrasi. Dalam penelitian ini menggunakan Johansen Cointegration Test. Hasil pengujian dianggap memiliki kointegrasi apabila trace statistic melebihi critical value. Setelah persamaan kointegrasi diketahui, maka analisis Vector Error Correction Model (VECM) dapat dilakukan.

\section{Uji Kausalitas Granger}

Metode kausalitas Granger adalah pengujian untuk menentukan hubungan sebab akibat antara peubah dalam sistem VAR. Prosedur pengujian dilakukan dengan menggunakan uji F. Kriteria pengujian pada uji kausalitas Granger adalah jika nilai Fhitung > Ftabel $(\alpha)$, tolak H0 berarti terdapat pengaruh yang signifikan secara statistik.

\section{Impulse Response Function (IRF)}

Analisis Impulse Response Function (IRF) merupakan analisis yang digunakan untuk menemukan respons suatu variabel endogen terhadap suatu guncangan tertentu. Dalam hal ini guncangan variabel ke- $i$ tidak hanya berpengaruh terhadap variabel tersebut tetapi ditransmisikan kepada seluruh variabel endogen lainnya. IRF dalam penelitian ini dilakukan untuk mengetahui respons dinamis pertumbuhan ekonomi sebagai variabel endogen terhadap guncangan variabel pertumbuhan ekonomi itu sendiri, variabel pembiayaan modal kerja, pembiayaan investasi dan pembiayaan konsumsi perbankan syariah. Dengan kata lain IRF ini digunakan untuk melacak respons saat ini dan masa depan setiap variabel akibat perubahan atau shock suatu variabel tertentu.

\section{Forecast Error Variance Decomposition (FEVD)}

Variance Decomposition (VDC) memisahkan varian yang ada di dalam variabel endogen menjadi komponen-komponen kejutan pada berbagai variabel endogen lainnya di dalam struktur dinamis VAR. VDC dapat digunkan untuk menyusun perkiraan error variance suatu variabel yaitu seberapa besarkah perbedaan antara variance sebelum dan sesudah diberikan kejutan baik kejutan yang berasal dari variabel lain ataupun variabel itu sendiri sehingga VDC dapat digunakan untuk mengkaji pengaruh relatif suatu variabel terhadap variabel lainnya. 


\section{PEMBAHASAN}

\section{Hasil Uji Stasioneritas Data}

Uji stasioneritas dilakukan dengan menggunakan Augmented Dickey-Fuller Test (ADF). Berdasarkan hasil yang diperoleh dari pengujian, data variabel tidak ada yang stasioner pada tingkat level sehingga diperlukan pengujian stasioneritas pada first difference-nya. Hasil pengujian pada tingkat first difference, menunjukkan bahwa hanya variabel GDP yang tidak stasioner, oleh karena itu akan dilakukan pengujian pada tingkat selanjutnya yaitu second difference. Pada pengujian tingkat second difference semua data variabel yang terdiri dari pertumbuhan ekonomi (GDP), pembiayaan modal kerja (CW), pembiayaan investasi (INV), dan pembiayaan konsumsi (CONS) stasioner dengan signifikansi $5 \%$.

Tabel 2 Rangkuman hasil uji unit root test

\begin{tabular}{lccc|lc}
\hline \multicolumn{2}{c|}{ Tingkat Level } & \multicolumn{2}{c}{ Tingkat First Different } & \multicolumn{2}{c}{ Tingkat Second Different } \\
\hline Variabel & Prob. & Variabel & Prob. & Variabel & Prob. \\
\hline GDP & 0.9999 & D $(\mathrm{GDP})$ & 0.9457 & $\mathrm{D}(\mathrm{GDP}, 2)$ & $0.0001^{*}$ \\
CW & 0.5348 & D $(\mathrm{CW})$ & $0.0000^{*}$ & D $(\mathrm{CW}, 2)$ & $0.0000^{*}$ \\
INV & 0.9999 & D(INV) & $0.0000^{*}$ & D(INV,2) & $0.0000^{*}$ \\
CONS & 0.9830 & D(CONS $)$ & $0.0010^{*}$ & D (CONS,2) & $0.0000^{*}$ \\
\hline
\end{tabular}

Keterangan: (*) nilai pengujian berdasarkan taraf nyata $5 \%$

\section{Uji Lag Optimum}

Penentuan lag maksimum dilakukan dengan menggunakan kriteria sequential modified LR test statistic. Berdasarkan hasil pengujian yang ditunjukkan oleh Tabel 3, diperoleh lag optimum maksimum berada pada lag ke-6.

Tabel 3 Hasil uji lag optimum

\begin{tabular}{ccccccc}
\hline Lag & LogL & LR & FPE & AIC & SC & HQ \\
\hline 0 & -1325.669 & NA & $1.45 \mathrm{e}+31$ & 83.10430 & 83.28752 & 83.16503 \\
1 & -1271.755 & 90.97948 & $1.37 \mathrm{e}+30$ & 80.73469 & 81.65077 & 81.03835 \\
2 & -1226.186 & 65.50488 & $2.28 \mathrm{e}+29$ & 78.88665 & 80.53560 & 79.43323 \\
3 & -1145.487 & $95.83109 *$ & $4.57 \mathrm{e}+27$ & 74.84291 & 77.22473 & 75.63242 \\
4 & -1121.548 & 22.44258 & $3.71 \mathrm{e}+27$ & 74.34674 & 77.46143 & 75.37917 \\
5 & -1094.354 & 18.69563 & $3.21 \mathrm{e}+27$ & 73.64713 & 77.49469 & 74.92249 \\
6 & -1058.856 & 15.53033 & $2.85 \mathrm{e}+27 *$ & $72.42852^{*}$ & $77.00894 *$ & $73.94680^{*}$ \\
\hline
\end{tabular}

Keterangan: Tanda (*) terbanyak menunjukkan lag optimum yang dipilih

\section{Uji Stabilitas VAR}

Berdasarkan uji stabilitas VAR yang diperlihatkan dari Tabel 4, model VAR dianggap stabil karena memiliki modulus lebih kecil dari satu yang terletak pada rentang 0.368095 sampai dengan 0.977010 . Sehingga dapat dilakukan uji pra-estimasi VECM selanjutnya.

\begin{tabular}{lc}
\multicolumn{2}{c}{ Tabel 4 Hasil uji stabilitas } \\
\hline \multicolumn{1}{c}{ Root } & Modulus \\
\hline$-0.028772-0.976587 \mathrm{i}$ & 0.977010 \\
$-0.028772+0.976587 \mathrm{i}$ & 0.977010 \\
-0.828977 & 0.828977 \\
$-0.541223-0.575126 \mathrm{i}$ & 0.789742 \\
$-0.541223+0.575126 \mathrm{i}$ & 0.789742 \\
-0.500625 & 0.500625 \\
$-0.108212-0.351830 \mathrm{i}$ & 0.368095 \\
$-0.108212+0.351830 \mathrm{i}$ & 0.368095 \\
\hline
\end{tabular}




\section{Uji Kointegrasi}

Uji kointegrasi dengan menggunakan uji Johansen Cointegration menunjukkan perbandingan antara trace statistic dengan critical value. Nilai trace statistic lebih besar dari critical value dengan taraf nyata 5\% sehingga terdapat tiga persamaan kointegrasi yang mampu menjelaskan hubungan jangka panjang antara variabel pada model VECM yaitu variabel pertumbuhan ekonomi, pembiayaan modal kerja, pembiayaan investasi dan pembiayaan konsumsi.

Tabel 5 Hasil uji kointegrasi

\begin{tabular}{|c|c|c|c|c|}
\hline \multicolumn{5}{|c|}{ Unrestricted Cointegration Rank Test (Trace) } \\
\hline Hypothesized & & Trace & 0.05 & \\
\hline No. of CE(s) & Eigenvalue & Statistic & Critical Value & Prob.** \\
\hline None * & 0.608719 & 59.97055 & 40.17493 & 0.0002 \\
\hline At most $1 *$ & 0.371125 & 29.00565 & 24.27596 & 0.0118 \\
\hline At most $2 *$ & 0.286070 & 13.69951 & 12.32090 & 0.0292 \\
\hline At most 3 & 0.075190 & 2.579506 & 4.129906 & 0.1279 \\
\hline
\end{tabular}

\section{Uji Kausalitas Granger}

Dari hasil pengujian kausalitas Granger, diketahui bahwa variabel yang mempunyai hubungan kausalitas adalah yang mempunyai nilai probabilitas yang lebih kecil dari alpha 0.05 sehingga $\mathrm{H} 0$ akan ditolak, yang berarti suatu variabel akan mempengaruhi variabel lain. Dari pengujian Granger diketahui hubungan kausalitas atau timbal balik variabel penelitian sebagai berikut:

a. Terjadi kausalitas searah antara pembiayaan modal kerja dan pertumbuhan ekonomi, yaitu hanya variabel pertumbuhan ekonomi yang secara statistik signifikan memengaruhi pembiayaan modal kerja dan tidak berlaku sebaliknya. Variabel pertumbuhan ekonomi (GDP) secara statistik berpengaruh signifikan terhadap pembiayaan modal kerja $(\mathrm{CW})$, sedangkan pembiayaan modal kerja secara statistik tidak berpengaruh terhadap pertumbuhan ekonomi.

b. Terjadi kausalitas searah antara pembiayaan investasi dan pertumbuhan ekonomi, yaitu hanya variabel pembiayaan investasi yang secara statistik signifikan memengaruhi variabel pertumbuhan ekonomi dan tidak berlaku sebaliknya. Variabel pertumbuhan ekonomi (GDP) secara statistik tidak berpengaruh terhadap pembiayaan investasi (INV), sedangkan variabel pembiayaan investasi secara statistik berpengaruh signifikan terhadap pertumbuhan ekonomi.

c. Terjadi kausalitas searah antara pembiayaan konsumsi dan pertumbuhan ekonomi, yaitu hanya variabel pembiayaan konsumsi yang secara statistik signifikan memengaruhi variabel pertumbuhan ekonomi dan tidak berlaku sebaliknya. Variabel pertumbuhan ekonomi (GDP) secara statistik tidak berpengaruh terhadap pembiayaan konsumsi (CONS), sedangkan variabel pembiayaan konsumsi secara statistik berpengaruh signifikan terhadap pertumbuhan ekonomi.

Tabel 6 Hasil uji kausalitas Granger

\begin{tabular}{lccc}
\hline Null Hypothesis: & Obs & F-Statistic & Prob. \\
\hline CW does not Granger Cause GDP & 34 & 4.29649 & 0.0056 \\
GDP does not Granger Cause CW & & 1.98553 & 0.1135 \\
\hline INV does not Granger Cause GDP & 34 & 1.75730 & 0.1571 \\
GDP does not Granger Cause INV & & 2.62173 & 0.0468 \\
\hline CONS does not Granger Cause GDP & 34 & 1.76365 & 0.1556 \\
GDP does not Granger Cause CONS & & 4.66303 & 0.0037 \\
\hline INV does not Granger Cause CW & 34 & 2.19676 & 0.0843 \\
CW does not Granger Cause INV & & 0.35142 & 0.9011 \\
\hline CONS does not Granger Cause CW & 34 & 2.04802 & 0.1039 \\
CW does not Granger Cause CONS & & 0.85189 & 0.5451 \\
\hline CONS does not Granger Cause INV & 34 & 1.04835 & 0.4233 \\
INV does not Granger Cause CONS & & 1.67837 & 0.1758 \\
\hline
\end{tabular}




\section{Hasil Estimasi VECM Pertumbuhan Ekonomi dan Variabel Lainnya}

Hasil estimasi VECM akan diperoleh hubungan jangka pendek dan jangka panjang antara pertumbuhan ekonomi, pembiayaan modal kerja, pembiayaan investasi dan pembiayaan konsumsi. Hasil estimasi jangka pendek menunjukkan bahwa variabel yang berpengaruh signifikan dalam jangka pendek terhadap pertumbuhan ekonomi adalah pembiayaan konsumsi pada 1 periode sebelumnya. Perubahan konsumsi 1 periode sebelumnya sebesar $1 \%$ akan memengaruhi penurunan pertumbuhan ekonomi saat ini sebesar $1.62 \%$.

GDP pada 3 periode sebelumnya berpengaruh signifikan dalam jangka pendek terhadap GDP saat ini. Perubahan GDP 3 periode sebelumnya sebesar 1 persen akan mempengaruhi penurunan GDP saat ini sebesar $0.94 \%$. Pembiyaan konsumsi pada $1,2,3$ periode sebelumnya berpengaruh signifikan terhadap pembiayaan modal kerja saat ini. Perubahan pembiayaan konsumsi 1, 2, dan 3 periode sebelumnya sebesar 1 persen akan memengaruhi penurunan pembiayaan modal kerja saat ini masingmasing sebesar $1.88 \%, 1.75 \%$ dan $1.29 \%$. GDP pada 3 dan 4 periode sebelumnya berpengaruh signifikan terhadap pembiayaan investasi saat ini. Perubahan GDP pada 3 dan 4 periode sebelumnya sebesar $1 \%$ akan memengaruhi penurunan pembiayaan investasi saat ini masing-masing sebesar $0.42 \%$ dan $0.32 \%$. GDP berpengaruh signifikan dalam jangka pendek pada 1,2 dan 3 periode sebelumnya terhadap pembiayaan konsumsi saat ini. Perubahan GDP pada 1, 2 dan 3 periode sebelumnya sebesar $1 \%$ akan memengaruhi penurunan pembiayaan konsumsi saat ini masing-masing sebesar $1.8 \%, 1.35 \%$ dan $0.85 \%$.

Tabel 7 Hasil uji pemodelan VECM (jangka pendek)

\begin{tabular}{lcccc}
\hline & D(GDP,3) & D(CW,3) & D(INV,3) & D(CONS,3) \\
\hline $\mathrm{D}(\mathrm{GDP}(-1), 3)$ & & & & -1.808452 \\
& & & & {$[-2.52641]$} \\
\hline $\mathrm{D}(\mathrm{GDP}(-2), 3)$ & & & -1.358934 \\
& & & {$[-2.63687]$} \\
\hline $\mathrm{D}(\mathrm{GDP}(-3), 3)$ & -0.941061 & & -0.428128 & -0.853778 \\
& {$[-2.82069]$} & & {$[-2.45232]$} & {$[-2.56384]$} \\
\hline $\mathrm{D}(\mathrm{GDP}(-4), 3)$ & & & -0.323188 & \\
& & & {$[-3.24712]$} & \\
\hline $\mathrm{D}(\mathrm{CONS}(-1), 3)$ & -1.618144 & -1.881997 & & \\
& {$[-2.13666]$} & {$[-2.67449]$} & \\
\hline $\mathrm{D}(\mathrm{CONS}(-2), 3)$ & & -1.754947 & & \\
& & {$[-2.68375]$} & \\
\hline $\mathrm{D}(\mathrm{CONS}(-3), 3)$ & & -1.299432 & \\
& & {$[-2.72678]$} & \\
\hline
\end{tabular}

Hasil estimasi jangka panjang menunjukkan bahwa hanya variabel pembiayaan konsumsi yang berpengaruh signifikan terhadap pertumbuhan ekonomi. Jika terjadi kenaikan pembiayaan konsumsi sebesar $1 \%$ maka akan menurunkan GDP sebesar $0.72 \%$.

Tabel 8 Hasil uji pemodelan VECM (jangka panjang)

\begin{tabular}{lccc}
\hline Cointegrating Eq: & CointEq1 & CointEq2 & CointEq3 \\
\hline D(GDP(-1),2) & 1.000000 & 0.000000 & 0.000000 \\
D(CW(-1),2) & 0.000000 & 1.000000 & 0.000000 \\
D(INV(-1),2) & 0.000000 & 0.000000 & 1.000000 \\
D(CONS(-1),2) & -0.724900 & -0.384547 & -0.110091 \\
& $(0.31676)$ & $(0.17494)$ & $(0.13055)$ \\
& {$[-2.28849]$} & {$[-2.19819]$} & {$[-0.84328]$} \\
\hline
\end{tabular}


Hasil penelitian ini sejalan dengan penelitian yang dilakukan oleh Afandi \& Amin (2019) yang menunjukkan hasil bahwa pembiayaan modal kerja dan pembiayaan investasi tidak signifikan berpengaruh terhadap pertumbuhan ekonomi Indonesia.

\section{Respons Pertumbuhan Ekonomi terhadap Guncangan suatu Variabel (Impulse Response Function)}

Hasil IRF menunjukkan tentang guncangan variabel pembiayaan modal kerja, pembiayaan investasi dan pembiayaan konsumsi terhadap pertumbuhan ekonomi. Ketika terjadi guncangan pada pembiayaan modal kerja, respons pertumbuhan ekonomi pada tahun pertama mengalami penurunan dan penurunan paling tinggi terjadi pada tahun ke-6 dan ke-10. Terlihat juga guncangan yang terjadi pada masing-masing variabel memiliki respons yang berbeda terhadap pertumbuhan ekonomi. Respons pertumbuhan ekonomi terhadap guncangan dari pembiayaan investasi memiliki respons positif dan stabil, menurun pada tahun ke-8 dan stabil kembali pada tahun berikutnya. Guncangan pembiayaan konsumsi terhadap pertumbuhan ekonomi menunjukkan respons yang positif dan stabil sampai pada tahun ke-5, kemudian menurun pada tahun ke-6 dan stabil kembali pada tahun berikutnya.
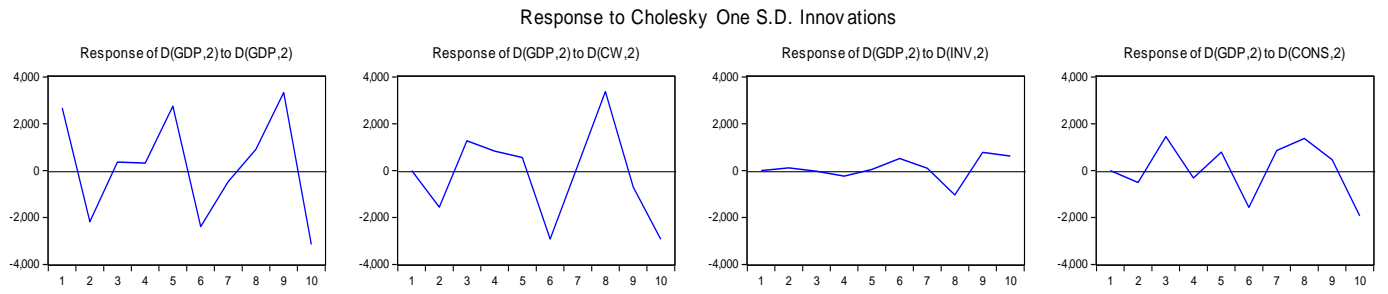

Gambar 1 Response to C holesky one S.D. innovations

\section{Kontribusi Variabel Independen dalam Memengaruhi Pertumbuhan Ekonomi}

Analisis FEVD menunjukkan bahwa kontribusi terbesar yang memengaruhi perubahan GDP adalah dirinya sendiri pada sebesar $100 \%$ pada periode 1 dan terus mengalami penurunan. Penurunan GDP diikuti oleh kenaikan kontribusi variabel lain yaitu pembiayaan modal kerja, pembiayaan investasi dan pembiayaan konsumsi. Kontribusi terbesar yang memengaruhi perubahan GDP selain dirinya sendiri adalah pembiayaan modal kerja sebesar $40.92 \%$ pada period ke-8, pembiayaan investasi sebesar $2.76 \%$ pada periode ke-9 dan pembiayaan konsumsi sebesar $13.72 \%$.

Tabel 9 Hasil uji FEVD

\begin{tabular}{ccccc}
\hline \multicolumn{6}{c}{ Variance Decomposition of $\boldsymbol{D}(\boldsymbol{G D P}, \mathbf{2})$ : } \\
\hline Period & D(GDP,2) & D(CW,2) & D(INV,2) & D(CONS,2) \\
\hline 1 & 100.0000 & 0.000000 & 0.000000 & 0.000000 \\
2 & 81.44912 & 16.68901 & 0.087450 & 1.774417 \\
3 & 65.09589 & 21.89552 & 0.072164 & 12.93642 \\
4 & 62.47468 & 24.37112 & 0.337570 & 12.81663 \\
5 & 70.57275 & 18.05533 & 0.245755 & 11.12616 \\
6 & 56.63745 & 30.21092 & 0.761515 & 12.39011 \\
7 & 55.86872 & 29.64366 & 0.766493 & 13.72113 \\
8 & 43.34000 & 40.92648 & 2.338274 & 13.39524 \\
9 & 51.17150 & 34.63749 & 2.764060 & 11.42694 \\
10 & 49.40876 & 35.44495 & 2.519692 & 12.62659 \\
\hline
\end{tabular}




\section{SIMPULAN}

Dalam jangka pendek maupun jangka panjang, pembiayaan konsumsi secara statistik berpengaruh negatif signifikan terhadap pertumbuhan ekonomi Indonesia. Pembiayaan perbankan syariah Indonesia menurut penggunaan dan kategori usaha yang terdiri dari pembiayaan modal kerja, pembiayaan investasi dan pembiayaan konsumsi telah ikut memberikan dinamika terhadap pertumbuhan ekonomi Indonesia. Kenaikan pembiayaan konsumsi dalam jangka pendek dan jangka panjang akan menurunkan pertumbuhan ekonomi, sehingga untuk memberikan kontribusinya terhadap pertumbuhan ekonomi Indonesia, maka perbankan syariah diharapkan untuk lebih mengoptimalkan pembiayaan jenis lain yang lebih produktif sehingga dapat berkontribusi terhadap pertumbuhan ekonomi Indonesia.

\section{DAFTAR PUSTAKA}

Abedifar, P., Hasan, I. \& Tarazi, A. (2016). Finance-growth nexus and dual-banking systems: Relative importance of Islamic banks. Journal of Economic Behavior \& Organization, 132, 198-215.

Afandi, M. A. \& Amin, M. (2019). Islamic bank financing and its effects on economic growth: A cross province analysis. Signifikan: Jurnal Ilmu Ekonomi, 8(2), 243-250.

Anwar, S. M., Junaidi, J., Salju, S., Wicaksono, R., \& Mispiyanti, M. (2020). Islamic bank contribution to Indonesian economic growth. International Journal of Islamic and Middle Eastern Finance and Management, 13(3), 519-532.

[BPS] Badan Pusat Statistik. (2019). Pendapatan Nasional Indonesia [Internet]. [diunduh 2020 Sep 5]. Tersedia pada: https://www.bps.go.id/publication/2020/06/12/7fe8d749c43bad46b1601662/ Pendapatan-nasional-indonesia-2015-2019.html.

[BPS] Badan Pusat Statistik. (2019). Seri PDP Indonesia 2010 [Internet]. [diunduh 2020 Sep 5]. Tersedia pada: https://www.bps.go.id/dynamictable/2016/02/09/1135/-seri-2010-pdb-triwulana n-atas-dasar-harga-konstan-2010-menurut-lapangan-usaha-miliar-rupiah-2010-2013.html.

El Ayyubi, S., Anggraeni, L., \& Mahiswari, A. D. (2018). Pengaruh bank syariah terhadap pertumbuhan ekonomi di Indonesia. Al-Muzara'ah, 5(2), 88-106.

Farahani, Y. G., \& Dastan, M. (2013). Analysis of Islamic banks' financing and economic growth: a panel cointegration approach. International Journal of Islamic and Middle Eastern Finance and Management, 6(2), 156-172.

Fasih, F. (2012). Inclusive growth in India through Islamic banking. Procedia-Social and Behavioral Sciences, 37, 97-110.

Hachicha, N. \& Amar, A. B. (2015). Does Islamic bank financing contribute to economic growth? The Malaysian case. International Journal of Islamic and Middle Eastern Finance and Management.

He, Q., \& Xu, B. (2019). Determinants of economic growth: a varying-coefficient path identification approach. Journal of Business Research, 101, 811-818.

Imam, P., \& Kpodar, K. (2016). Islamic banking: Good for growth? Economic Modelling, 59, 387401.

Lebdaoui, H. \& Wild, J. (2016). Islamic banking presence and economic growth in Southeast Asia. International Journal of Islamic and Middle Eastern Finance and Management, 9(4), 551-569.

Lee, J. W., \& Hong, K. (2012). Economic growth in Asia: Determinants and prospects. Japan and the World Economy, 24(2), 101-113.

Mahzalena, Y., \& Juliansyah, H. (2019). Pengaruh inflasi, pengeluaran pemerintah dan ekspor terhadap pertumbuhan ekonomi di Indonesia. Jurnal Ekonomi Regional Unimal, 2(1), 37-50.

Majid, M. S. A. \& Kassim, S. H. (2015). Assessing the contribution of Islamic finance to economic growth. Journal of Islamic Accounting and Business Research, 6(2), 292-310.

[OJK] Otoritas Jasa Keuangan. (2019). Roadmap Pengembangan Keuangan Syariah [Internet]. [diunduh pada 2020 Sep 5]. Tersedia pada: https://www.ojk.go.id/id/kanal/syariah/berita -dan-kegiatan/publikasi/Documents/Pages/Roadmap-Pengembangan-Keuangan-Syariah-Indone sia-2017-2019/Roadmap\%202017-2019(1).pdf. 
[OJK] Otoritas Jasa Keuangan. (2019). Statistik Perbankan Syariah 2019 [Internet]. [diunduh pada 2020 Sep 5]. Tersedia pada: https://www.ojk.go.id/id/kanal/syariah/data-dan-statistik/statistikperbankan-syariah/Documents/Pages/Statistik-Perbankan-Syariah---Desember-2019/SPS\%20D esember\%202019.pdf.

Rizvi, S. A. R., Narayan, P. K., Sakti, A., \& Syarifuddin, F. (2019). Role of Islamic banks in Indonesian banking industry: an empirical exploration. Pacific Basin Finance Journal, February, 62.

Rusliani, H. (2018). Ekonomi syari'ah solusi dalam menghadapi krisis moneter (perbandingan Malaysia-Indonesia). Al-Amwal: Jurnal Ekonomi dan Perbankan Syari'ah, 10(2), 199-214.

Sarwer, M. S., Ramzan, M., \& Ahmad, W. (2013). Does islamic banking system contributes to economy development. Global Journal of Management and Business Research, 13(2).

Sulistiana, I. (2017). Model Vector Auto Regression (VAR) and Vector Error Correction Model (VECM) approach for inflation relations analysis, Gross Regional Domestic Product (GDP), world tin price, BI rate and rupiah exchange rate. Integrated Journal of Business and Economics, 1(2), 17-32.

Tabash, M. I., \& Dhankar, R. S. (2014). Islamic banking and economic growth: An empirical evidence from Qatar. Journal of Applied Economics and Business, 2(1), 51-67.

Yusof, R. M., \& Bahlous, M. (2013). Islamic banking and economic growth in GCC \& East Asia countries. Journal of Islamic Accounting and Business Research, 4(2), 151-172. 